\title{
MUTUAL LEGAL ASSISTANCE IN CRIMINAL MATTERS IN THE PROCESS OF DEALING WITH CHILD SEXUAL ABUSE CASES IN VIETNAM
}

\author{
Do Thi Phuong ${ }^{1}$ \\ Ha Noi Law University, Vietnam \\ phuonghlu@gmail.com
}

\section{Abstract}

International cooperation can be understood as competent bodies of the Social Republic of Vietnam and other countries coordinating, supporting each other in investigation, prosecution, adjudication and execution of criminal cases. International cooperation in criminal procedure includes mutual legal assistance in criminal, extradition, receipt and transfer of prisoners and other activities as stipulated in Criminal Procedure Code 2015, international laws on mutual legal assistance and conventions of which the Social Republic of Vietnam is a member.

Child sexual abuse cases in Vietnam and other countries in the world, especially in ASEAN region, have become increasingly complicated. Many Vietnamese children were and have been victims of sex trafficking to foreign countries, a lot of them were fooled by job opportunities and then were sold into prostitution near the border of China, Cambodia, Laos and other Asian countries, namely Malaysia, Korea, Singapore, Taiwan and Thailand... Therefore, prevention of child sexual abuse is an integral task and a top priority of Vietnam currently. Solving child sexual abuse cases consisting of international factors requires Vietnam to have close international cooperation with other countries.

This article focuses on the analysis of the provisions of criminal procedure law and the practical implementation of mutual legal assistance in the process of solving child sexual abuse cases. In

\footnotetext{
${ }^{1}$ Assoc.Prof. Dr. (Law), Head of Criminal Investigation Science Department, Faculty of Criminal Law, Hanoi Law University.

87 Nguyen Chi Thanh Str., Dong Da Dist., Hanoi, Vietnam.
} 
addition, the article provides solutions to improve the effectiveness of mutual legal assistance in solving child sexual abuse cases.

\section{Keywords}

Child sexual abuse; mutual legal assistance in criminal matters; Viet Nam; Criminal Procedure Code

\section{CONTENTS}

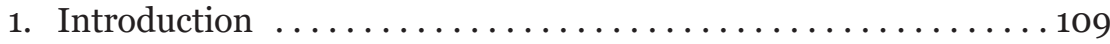

2. Concept of Mutual legal assistance (MLA) in criminal matters in the process of dealing with child sexual abuse cases ....... 110

3. Vietnam criminal procedure law on MLA in the process of dealing with child sexual abuse cases . .............. 113

4. Practical implementation of MLA in dealing with child sexual abuse cases in Vietnam ............... 116

5. Some solutions to improve the effectiveness of MLA activities in dealing with child sexual abuse cases in Vietnam ......... 120

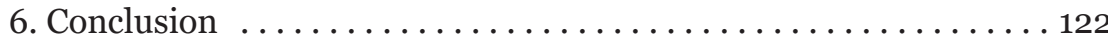

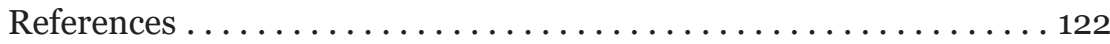

\section{Introduction}

Nowadays, no country in the world can survive and develop on its own without the connection with other countries. This means international cooperation is not only the internal necessity of a country itself for its socio-economic development, but also has the responsibility and obligation of each country under the view of international laws. The growth of international integration, especially, the establishment of ASEAN community has brought about a lot of favorable conditions and difficulties to the practice of law enforcement. In terms of child sexual abuse offences, integration and open policies for travelling and business might indirectly lead to the development of this kind of crimes. Therefore, strengthening mutual legal assistance in criminal matters between Viet Nam and foreign countries to promptly restrain crimes and ensure the legal cooperation on criminal cases has become a current issue. 


\section{Concept of Mutual legal assistance (MLA) in criminal matters in the process of dealing with child sexual abuse cases}

Mutual legal assistance plays an important role in the criminal proceedings of each country and in the regulations of international criminal laws. Aiming at supporting the domestic criminal law enforcement, the government of each country cooperates with one another in transferring offenders and executing other relevant measures of criminal investigation, including collecting and providing evidence.

Every country has the supreme power, especially the jurisdiction within its territory to carry out legislature, executive, judicial activities and other necessary management activities to its agencies, organizations, citizens in all fields. When the courts or competent agencies of a country have to handle a foreign-related case, they will not only base on the national laws and international treaties that the country is a party to, but in many cases, they also have to seek for the assistance from the courts and competent agencies of foreign countries in carrying out several independent procedures that are necessary for the cases. However, it is difficult for a country to perform its jurisdiction on its agencies, organizations, citizens in the territory of other countries without their permission. That is why mutual legal assistance (including service of papers, documents, collecting evidences, assistance in investigation...) of functional agencies in foreign countries is necessary in that circumstances.

Internationally, MLA is also interpreted as a concrete manifestation of national sovereignty that other countries must respect and must not force or interfere in the internal affairs of that nation under any circumstances. As a result of declaring a national sovereignty and criminal procedure activities that can be proceeded or cannot be proceeded as well as minimum requirements to be followed, each nation has different laws regulating MLA. Mutual legal assistance and international cooperation in preventing and dealing with crimes must be considered as a kind of indispensable requirements in the current context of strong growth in international relations in general and in civil, economic-business interactions among organizations, persons of various nations in particular. 
On 24 October 1970, United Nations General Assembly issued the Declaration of Principles of International Law concerning Friendly Relations and Cooperation Among States in accordance with the Charter of the United Nations, accordingly, every nation, the basic subject of international law, is obligated to cooperate with each other. The scope of cooperation obligation is very large, including mutual legal assistance in criminal matters. ${ }^{2}$

Recently, there are various opinions about mutual legal assistance, for example: "Mutual legal assistance in criminal matters is an international legal procedure that procedure-conducting bodies of relevant nations cooperate with one another in assisting the collection and provision of information, evidence, testimony and other relevant documents under international treaties, national laws aiming at investigating, handling foreign-related criminal cases."3

Another opinion: "Mutual legal assistance in criminal matters is an international legal procedure that procedure-conducting bodies of relevant nations cooperate with one another in assisting the collection and providing of information, evidence, testimony and other relevant documents; conducting extradition of offenders."4

In our opinions, Mutual legal assistance in criminal matters is the exercise by the competent bodies in the proceedings of this country to conduct legal proceedings or proceedings as required by the competent bodies in the proceedings of the other country on the basis of the agreement of the respective countries.

The concept "children" is defined in many different documents. According to Law on Children adopted by National Assembly of S.R. Viet Nam on 5 April 2016, "children" is defined as persons under 16 years old. Among variety of understanding about "children", we can conclude that "children are those who are in the period of growing,

${ }^{2}$ G.A. Declaration of Principles of International Law concerning Friendly Relations and Cooperation Among States in accordance with the Charter of the United Nations - Resolution 2625 (XXV), 6, 1970.

${ }^{3}$ Ngọc Anh Nguyen, Van Manh Nguyen, Van Cong Pham, at 16, Mutual legal assistance, theoritical and practical issues, People's Police Publishing House (2009).

${ }_{4}^{4}$ Institute of Strategy and Science under Ministry of Public Security, at 1261, People's Police Encyclopedia Dictionary of Viet Nam, People's Police Publishing House (2005). 
have not matured physically and mentally, are vulnerable to negative effects of social environment. Law on Children 2016 stipulates that agencies, organizations, education institutions, families and persons are responsible for taking proper measures to ensure the safe and healthy life of children; preventing and handling child abuse activities. Nevertheless, in fact, child sexual abuse crimes have developed complicatedly with many new artifices. Child sexual abuser is using violence or threatening to use violence, forcing, implicating, enticing children to participate in sexual activities, such as: rape, rape of the caredependent persons or persons in extreme difficulties, sexual intercourse with children, molestation of children, and using for pornographic purposes. Pursuant to Article 34 of the Convention on the rights of the child (1989), States Parties undertake to protect the child from all forms of sexual exploitation and sexual abuse, States Parties shall in particular take all appropriate national, bilateral and multilateral measures to prevent the inducement or coercion of a child to engage in any unlawful sexual activity. Other relevant international legal documents are The Optional Protocol to the Convention on the Rights of the Child on children trafficking and pornography of (20oo), United Nations Convention against Transnational Organized Crimes (200o) (UNTOC) and Protocol to Prevent, Suppress and Punish Trafficking in Persons, especially Women and Children of UNTOC (2005) (Protocol BBN). The practice in Viet Nam shows that there are some kinds of sexual abuse crimes frequently happening, such as: rape of a child, rape of a care-dependent child or child in extreme difficulties, sexual intercourse with a child, molestation of a child. Some localities sharing border with neighboring countries also witnessed an increase in the number of child trafficking, child swapping, child abduction with the aim of sexual abuse. To protect children against sexual abuse, apart from conclusion of Treaties on mutual legal assistance in criminal matters, procedure-conducting bodies have to ensure the prompt and impartial exercises in mutual legal assistance relating to the handling of child sexual abuse cases.

It can be defined that, mutual legal assistance in criminal matters relating to the handling of child sexual abuse cases is the exercise of legal proceedings or proceedings, done by the competent bodies of a 
country as required by the competent bodies in the proceedings of another country on the basis of the agreement between these countries on serving the investigation, prosecution, adjudication and execution of criminal judgement relating to child sexual abuse.

The content of legal assistance in criminal matters relating to child sexual abuse cases include: executing mutual legal assistance requests and transfer of case files, documents, materials and items of child sexual abuse cases. Mutual legal assistance in criminal matters is performed under the forms of making the requests to foreign countries or executing the requests from foreign countries between competent agencies of relevant countries for assisting in conducting procedure acts that are necessary for handling foreign-related criminal cases. Through which, competent criminal justice authorities of relevant countries will collect documents, evidence, testimony, conduct the search and arrest of offenders and other procedural activities in accordance with the concerning international treaties or reciprocity principle. The subjects which have the jurisdiction to execute mutual legal assistance will be defined by national law, they normally are criminal judicial authorities. Almost all countries tend to define their Central Authority as receiving and transferring mutual legal assistance requests and the system of criminal justice bodies executing concrete mutual legal assistance activities.

\section{Vietnam criminal procedure law on MLA in the process of dealing with child sexual abuse cases}

Before Criminal Procedure Code 2015 becoming effective, Criminal Procedure Code 2003 included for the first time regulations on international cooperation in criminal proceedings, seven articles in two chapters (from Article 340 to Article 346), and then Law on Mutual legal assistance 2007 was adopted and became effective on 1 July 2008. These two laws has worked as the legal framework for procedure-conducting bodies in Vietnam and their foreign counterparts to cooperate and assist one another in carrying out international legal assistance activities, such as: mutual legal assistance in criminal matters, extradition, and transferring a person who is serving a sentence of imprisonment. 
However, in the context of deep and wide international integration and globalization, there is an increase in crimes and especially foreignrelated crimes, transnational crimes of a highly complicated degree and committing artifice. Accordingly, there has been a higher demand for international cooperation in criminal proceedings in reality, meanwhile, many bilateral and multilateral treaties have been concluded in Vietnam, but relevant regulations have not been stipulated in Criminal Procedure Code 2003 and Law on Mutual legal assistance 2007. Foreseeably, there is a gap between Criminal Procedure Code 2003, Law on Mutual legal assistance 2007 and the actual demands. ${ }^{5}$ Besides, the guiding documents of Laws are also contradictory and different from one another, for example, the lack of regulations on payment of costs for executing requests for Mutual legal assistance in civil matters, causing the effect to firm implementing Mutual legal assistance between Vietnam and countries to which Vietnam has not concluded Mutual legal assistance Treaty. The contents of Article 17 Law on Mutual legal assistance are not adaptable to Vietnam's international commitment and does not meet the actual demands. ${ }^{6}$ Hence, Criminal Procedure Code 2015 with a lot of amendments relating to this issue aims at improving the legal framework for conducting international cooperation in criminal proceedings. There are following new regulations:

- International Cooperation in criminal proceedings is the assistance and support from competent agencies of the Socialist Republic of Vietnam and competent agencies of foreign countries for performing activities supporting the investigation, prosecution and adjudication of criminal cases and execution of criminal judgments.

- International Cooperation in criminal proceedings consists of mutual legal assistance in criminal matters, extradition, transferring a person who is serving a sentence of imprisonment and other international cooperation activities as defined in the Criminal Procedure Code, Mutual Legal Assistance laws and international treaties to which Vietnam is a party.

5 Moj, Report on Summary of 6 years implementing Law on Mutual Legal 2007 (2014).

${ }^{6}$ Ngoc Anh Nguyen, International Cooperation of Vietnamese People's Police force in prevention and fight against crimes, Justice Publishing House, at 20 (2007). 
- International Cooperation in criminal proceedings within the territory of the Socialist Republic of Vietnam is conducted in accordance with international treaties to which Vietnam is a party or reciprocity principle, Criminal procedure code, law on mutual legal assistance and other relevant regulations of Vietnam.

Many regulations on mutual legal assistance in criminal proceedings were stipulated in detail and more comprehensively, for instance:

"Materials, items collected by competent agencies of foreign countries as requested by competent agencies of Vietnam or materials, items transferred by competent agencies of foreign countries for prosecuting one's criminal liability might be viewed as evidence. In cases these materials and items having the characters defined in Article 89 of Criminal Procedure Code, will be viewed as exhibits."

In terms of receiving, transferring materials and items relating to the cases:

"Receiving, transferring materials, items relating to the cases shall be conducted in accordance with international treaties to which the Socialist Republic of Vietnam is a party, regulations of this Code, Law on mutual legal assistance and other relevant regulations of Vietnam."

Based on Criminal Procedure Code and other legal documents concerning mutual legal assistance in criminal proceedings, competent procedure-conducting bodies of Vietnam have made a variety of requests for mutual legal assistance to foreign countries in the process of dealing with criminal cases. Some agencies have asked foreign countries to provide information via INTERPOL Office under Ministry of Public Security; some agencies dispatched their officers from foreign countries for collecting materials; some others made requests for mutual legal assistance and sent to the Supreme People's Procuracy of Vietnam, the Central Authority of Vietnam in Mutual legal assistance in criminal matters, for asking foreign countries to assist in collecting and providing materials and evidence; procedure-conducting bodies in

7 Criminal Procedure Code 2015, National Politics Publishing House, Hanoi, 2015. Article 494

${ }^{8}$ Criminal Procedure Code 2015, National Politics Publishing House, Hanoi, 2015. Article 497. 
localities sharing border with neighboring countries like China, Laos and Cambodia are allowed to make requests for direct assistance. The results of Mutual legal assistance in criminal matters are used as evidence for the cases.

\section{Practical implementation of MLA in dealing with child sexual abuse cases in Vietnam}

Over the recent years, child sexual abuse crimes have developed complicatedly despite the strong restraint. In 2017, 1592 cases were detected, declining by 3 percent from last year. In the first half of 2018, 700 sexual abuse cases were detected, o percent of the victims are baby girls. Under the impact of globalization, transnational crimes including human trafficking (with the purpose of sexual abuse) tend to increase. Recently, the number of requests for mutual legal assistance in criminal matters between Vietnam and foreign countries has increased rapidly, the contents of requests have become more and more complicated. 80 percent of human trafficking victims in Vietnam are ethnic minority women and children. ${ }^{9}$ Criminal justice authorities of Vietnam have instituted 1000 criminal cases with 2000 accused involving human trafficking. The number of victims is 3100 persons, of whom 519 persons have not been rescued. The majority of victims were trafficked to China and were forced to marry the locals, were sexually abused and forced to work. ${ }^{10}$

In terms of Requests for mutual legal assistance (MLA) in criminal matters sent by competent procedure-conducting bodies of foreign countries to Vietnam:

During the period of 2011 and 2015, Supreme People's Procuracy (SPP) of Vietnam received and dealt with 341 MLA requests from foreign countries, 84 percent of which came from countries having

${ }^{9}$ National Assembly Judiciary Committee, Statistics in the hearing on implementation of laws on prevention and combatting human trafficking crimes between 2012 and 2017 organized by National Judiciary Committee in the morning of 23/8/2018 in Hanoi.

${ }_{10}$ Duc Minh, $80 \%$ of trafficking victims are sexually exploited (August 24, 2018) (https://plo.vn/xa-hoi/8o-nan-nhan-mua-ban-nguoi-bi-boc-lot-tinh-duc-789117. html). 
MLA treaties with Vietnam like: Czech Republic, Russia, Hungary and South Korea). ${ }^{11}$ The contents of MLA requests are mainly identifying, collecting, providing evidence, services of documents, papers, transfer for prosecuting one's criminal liability.

The reality shows that the Southeast Asian countries have become a favorite destination for child sexual abusers because of their developing economy with affordable price services, stable political condition, undisciplined legal system. Among 11 Southeast Asian countries, Thailand is "the leading country" in child sexual abuse tourism. Cambodia is the second one, where 33 thousand children are forced to work in prostitution service institutions, Indonesia is also one of the "top countries”. Thailand has recently taken tougher measures on managing child sexual abuse tourism, Cambodia, Vietnam, Laos and Myanmar are eventually attractive to child sexual abusers instead. Vietnam witnessed an increase in the number of child sexual abuse cases relating to foreign tourists. Apart from benefits brought by tourism, Vietnam is now facing a lot of negative impacts including the increase of child sexual abuse. ${ }^{12}$

In reality, offenders coming to Vietnam by different ways committed child sexual abuse crimes. For example, in May 2013, competent agencies of France issued the international wanted notice against Larroque Olivier, French nationality, a doctor, for committing child sexual abuse acts and raping children. France requested Interpol in various countries to arrest him once detecting and extradite him in accordance with the national laws of the requested countries or bilateral, multilateral treaties. After being detected and arrested by competent agencies of Vietnam, Larroque Olivier stated that he immigrated to Vietnam in 2000, worked six weeks per year in a hospital of Hanoi under a contract. After that, Vietnam conducted the extradition procedures against Larroque Olivier. ${ }^{13}$

${ }^{11}$ Report on Summary of implementation of mutual legal assistance in criminal matters by SPP of Vietnam between 2011 and 2015 .

${ }_{12}$ Duc Tran, Cooperation in preventing child sexual abuse in tourism: New but active (Oct. 1, 2013) (https://congly.vn/thoi-su/thoi-cuoc/hop-tac-phong-chongxam-hai-tinh-duc-tre-em-trong-du-lich-moi-me-nhung-chu-dong-31608.html).

${ }_{13}$ Huong-Bac-Duc, Portrait of French doctor sexually assaulting hundreds of Vietnamese children (May 5, 2015) (https://baomoi.com/chan-dung-bac-si-phapxam-hai-tinh-duc-tram-tre-em-viet/c/16620192.epi). 
In terms of MLA requests of Vietnamese procedure-conducting agencies to foreign countries:

In the period from July 2008 to June 2018, the SPP received 926 MLA requests of domestic competent procedure-conducting bodies and sent to foreign countries for execution, 341 of which received the results from foreign countries. About 70 percent of MLA requests of Vietnam were sent to following countries, territories: Laos, China, Hong Kong, Singapore, Malaysia, South Korea... the number of requests tends to increase quickly. MLA activities mainly occurred in the stage of investigation. ${ }^{14}$

MLA requests related to collecting and providing evidence, documents, papers, identification of offender judicial curriculum vitae of Vietnamese citizens or foreigners committing crimes in Vietnam. Human trafficking and rape are two kinds of crimes were mentioned in MLA requests.

Prime Minister approved the Program on Prevention and fight against human trafficking in the period of 2016 and 2020, in which international cooperation with three neighboring countries including China, Laos, Cambodia is a focal point. Accordingly, from 2016 up to now, Border Guard force of Vietnam has successfully addressed 27 special cases, arrested and handled 167 cases with 125 perpetrators, prosecuted and handed over to the Police Investigation Agency 53 cases with 81 subjects, a total of 430 victims, including 206 rescued victims, 110 received victims, 114 self-returned victims. Every year, coordination and international cooperation between Vietnam's border guard forces and the anti-trafficking forces of the three neighboring countries are carried out regularly over 10 human trafficking cases. ${ }^{15}$

The child abuse crimes in the form of trafficking, abduction are not numerous but the consequences and danger occurring towards children are very serious. The children who were fooled be sold to China were sexually exploited with extreme cruelty. It is difficult to detect these crimes, or if they are found, the handling of the subject is very difficult,

${ }^{14}$ SPP, Report on MLA activities between 2011-2018.

${ }_{15}$ Trung Nguyen, Coordination in activities of preventing and fighting against human trafficking crimes (July 1, 2018) (http://www.bienphong.com.vn/phoi-hopdau-tranh-phong-chong-mua-ban-nguoi/,). 
because the perpetrators are living in China, whereas the international cooperation to combat this crime is limited. The fact that procedures must go through many levels, take a lot of time, greatly affect the proving of crime. ${ }^{16}$ In addition, the Supreme People's Procuracy of Vietnam has coordinated with the Ministry of Public Security of Vietnam to facilitate and assist foreign procedure-conducting persons to come to Vietnam for witnessing the implementation process of MLA requests or sending investigators abroad to testify in cases involving Vietnamese citizens. ${ }^{17}$

It is possible to recognize the shortcomings and limitations of MLA in Vietnam in general and child sexual abuse cases in particular as the following main points:

- The development of legal regulations (including domestic legal documents and related international treaties) for serving MLA in criminal proceedings in Vietnam has been fulfilled. However, there are still many shortcomings and obstacles, leading to difficulties for the agencies performing MLA in criminal proceedings.

- The dissemination and fostering of knowledge of international law, guiding MLA skills and foreign languages for procedure-conducting persons are not regular and have not been properly invested in. Vietnam has not built up a group of professional negotiators who have specialized legal skills, who have the skills to negotiate and have foreign languages at a level comparable to the job requirements, especially negotiating MLA treaties, which often involve complex international legal issues as the legal systems of each country are different.

- The examination and periodical evaluation of MLA activities has been carried out annually but has not been paid enough attention and performed thoroughly. The competent bodies have not yet found out the causes of limitations in MLA in order to enhance this process. The coordination between Supreme People's Procuracy and Ministries

${ }_{16}$ Thai Hung, Situation and results of prevention and fight by People's Procuracy of Quang Ninh province against child sexual abuse (Apr. 01, 2013). (http://vksndtc. gov.vn/tin-chi-ti- et-3222).

${ }_{17}$ Duc Minh, $80 \%$ of trafficking victims are sexually exploited (August 24, 2018) (https://plo.vn/xa-hoi/8o-nan-nhan-mua-ban-nguoi-bi-boc-lot-tinh-duc-789117. html). 
has not yet been strengthen in terms of negotiating, signing and implementation MLA treaties.

- The length of time spent on executing MLA requests is long (many cases lasted for years) that do not meet the requirements of the time limit of adjudication domestically, thus, affecting the proceedings. It can be seen that the effectiveness of MLA is limited due to shortcomings in making MLA requests which is in charge of the Vietnamese agencies, such as Judicial: Dossiers of MLA requests made by Vietnamese competent agencies in contravention of law, including the payment of fees, were not executed by foreign countries even though they had been sent to competent agencies...

\section{Some solutions to improve the effectiveness of MLA activities in dealing with child sexual abuse cases in Vietnam}

Firstly, it is necessary to intensify negotiations conclusion of MLA treaties with other countries in the world, with priority given to the negotiation and conclusion of MLA treaties with ASEAN member countries and China. In addition to consolidating, strengthening and establishing cooperation between Vietnam and other countries in the world, especially those with traditional ties, border-sharing countries and member countries of ASEAN for concluding MLA treaties, Vietnam needs to strengthen its cooperation with international agencies and organizations that have the function of preventing and combating crimes in around the world such as ASEANPOL, UNODC, INTERPOL as well as judicial agencies, law enforcement agencies of countries in the continent and over the world.

Regarding the content of cooperation, attention should be given to the following areas: exchanging information and databases relating to crime; wanted criminals; transferring of MLA requests; consultancy, policy making, development of laws; exchanging experience and professional knowledge; training officials between the Vietnamese Police and ASEANPOL, INTERPOL, UNODC as well as between Vietnamese judicial authorities and judicial authorities of countries in the region and the world. On the form of cooperation, through meetings, international forums, conferences and seminars on the review or 
implementation of action programs on the prevention and combat of crimes and mutual legal assistance in criminal matters co-organized by the General Assembly of ASEANPOL, INTERPOL, UNODC or other judicial bodies of other countries. These agencies and organizations shall make summaries and assessments on the crime situation and on the results of MLA in criminal matters as well issuing resolutions to draw experiences or provide guidelines and recommendations for the anti-crime bodies of member countries to apply.

Secondly, overall reviewing of MLA treaties concluded by Viet Nam prior to the 2007 Mutual Legal Assistance Law for the purpose of negotiating, amending or supplementing MLA treaties with the countries concerned. Creating a common legal framework among nations in the fight against child sexual abuse crimes is a top priority. Therefore: (1) It is necessary to step up bilateral or multilateral MLA treaties, extradition of criminals between countries with emphasis on cooperation in combating sexual crimes relating to tourism; (2) Organizing study tours and seminars to exchange experiences in the fight against this type of crimes among experts of countries in the region and in the world; (3) There should be close cooperation mechanisms between countries and international and regional organizations of prevention and fight against crimes such as Interpol, ASIANPOL to maximize the advantages of these organizations in coordination to hunt down criminals.

Thirdly, to raise the capacity and quality of competent procedure conducting persons in Vietnam and those related to the MLA activities in criminal proceedings. The effectiveness of MLA activities depends much on those who have the authority to conduct the proceedings. To do so, it is necessary to strengthen international cooperation in training and intensive training in order to improve professional skills, legal knowledge and foreign languages for staff working in the prevention and combat of transnational crimes, foreign- related crimes. To take the initiative in co-hosting the international conferences, seminars and training courses of Interpol, which are related to activities of combating transnational organized crimes and foreign-related crimes. In addition, Vietnam needs to study and accelerate the development of the Law on Extradition, fully domesticize Vietnam's international commitments. Law on extradition must stipulate principles of extradition, refusal of 
extradition, procedures of extradition in order to meet the practical requirements of combating crimes in the context of globalization, international integration and judicial reform.

Fourthly, to further promote propagation and communication concerning regulations on child protection, care and education in order to raise the awareness among people, especially people in border areas and National key tourist sites for child sexual abuse criminals. The propagation and dissemination of laws must have specific plans and programs for short and long-term aims, focusing on integrating communication contents into the daily life of residential zones, into the extracurricular activities of all educational levels and activities of organizations at all levels, it is necessary to step up the implementation of the movement to build cultural families and civilized lifestyles in the population community. Attention should be paid to the form of consultation, counseling and direct conversation with families and communities about skills to protect children from danger; to strengthening the inspection and supervision of child protection and care at the grassroots level, thus contributing to minimize the situation of children suffering from violence and sexual abuse.

\section{Conclusion}

Mutual legal assistance holds an important role in the criminal proceedings of each country and in the provisions of international criminal law. The content of this paper focuses on the analysis of the provisions of criminal procedure law and the practical implementation of judicial assistance in the process of solving child sexual abuse cases. In addition, the article provides solutions to improve the effectiveness of criminal justice mutual assistance in dealing with cases involving child sexual abuse.

\section{REFERENCES}

1. Duc Tran, Cooperation in preventing child sexual abuse in tourism: New but active, (2013).

2. Duc Minh, $80 \%$ of trafficking victims are sexually exploited (August 24, 2018) (https://plo.vn/xa-hoi/8o-nan-nhan-mua-bannguoi-bi-boc-lot-tinh-duc-789117.html). 
3. Huong-Bac-Duc, Portrait of French doctor sexually assaulting hundreds of Vietnamese children (May 5, 2015) (https://baomoi. com/chan-dung-bac-si-phap-xam-hai-tinh-duc-tram-tre-em-viet/c/ 16620192.epi).

4. Institute of Strategy and Science under Minstry of Public Security, People's Police Enclopedia Dictionary of Viet Nam, People's Police Publishing House, at 1261 (2005).

5. Ngoc Anh Nguyen, Van Manh Nguyen, Van Cong Nguyen, Mutual legal assistance, theoretical and practical issues, People's Police Publishing House, at 16 (2009).

6. Ngoc Anh Nguyen, International Cooperation of Vietnamese People's Police force in prevention and fight against crimes, Justice Publishing House, at 20 (2007).

7. Thai Hung, Situation and results of prevention and fight by People's Procuracy of Quang Ninh province against child sexual abuse posted on 01/04/2013, http://vksndtc.gov.vn/tin-chi-ti- et-3222.

8. Trung Nguyen, Coordination in activities of preventing and fighting against human trafficking crimes (July 1, 2018) (http:// www.bienphong.com.vn/phoi-hop-dau-tranh-phong-chong-mua-bannguoi/,). 